From the editor. In issues 1-2 of the journal "Studies on Russian Economic Development" for 2021, we publish articles by our Chinese colleague, Xu Wenhong, a researcher at the Institute of Russian, East European and Central Asian Studies of the Chinese Academy of Social Sciences. Despite the fact that this text examines not only economic, but also political changes in Russia that have occurred in the past 20 years, it seemed to us important to look at the transformation of economic and financial policy in Russia by a representative of Chinese economic science. Many things that seem obvious to us look different from abroad. It is all the more interesting that the author sees lessons for China in the development of the Russian economy.

\title{
Basic Concepts of Russia’s Fiscal Policy: Experience for China Part 2
}

\author{
Xu Wenhong* \\ Institute of Russian, Eastern European and Central Asian Studies, Chinese Academy of Social Sciences, Beijing, 10000 China \\ *e-mail: schirov-mse@yandex.ru \\ Received October 12, 2020; revised November 10, 2020; accepted November 16, 2020
}

\begin{abstract}
Financial activities are the government's material means of leveraging financial resources, maintaining the exercise of political power and achieving administrative goals through financial revenues and expenditures. Successive administrations have been learning lessons from their predecessors, exploring the government's financial goals in response to Russia's severe economic and social problems and constantly adjusting themselves according to the changing situation. These goals include privatization and property right reform (expansion of the financial base), transfer payment and redistribution (consolidation of the public base of the regime), economic regulation (stimulation of economic growth, exchange rate stability, reduction of inflation, and tax neutrality), and the guarantee of financial security (budget balance and expansion of reserves), which have gradually led to a set of relatively stable financial rules in the years. The first part analyzes the activities of seven prime ministers during the Putin era. The second part examines the fiscal policy of Russia over the past 20 years.
\end{abstract}

Keywords: the putin era, fiscal policy, exchange rate policy, financial sanctions

DOI: $10.1134 / \mathrm{S} 1075700721020155$

Privatization and property right reform. The adjustment of fiscal policy usually goes hand in hand with the reform in the country's basic economic system and mechanism. 70 years of rigid system led to the disintegration of the Soviet Union, and the privatization in the 1990s led to the emergence of oligarchs. Oligarchy has seriously affected Russia's political and economic life. To avoid mistakes in the previous years, end the oligopolistic economy and establish a new property right system are the inevitable choices that V. Putin has to make for state governance.

V. Putin carried out reforms in the property right system and began to implement mixed ownership. The new "Law on Privatization of State- and MunicipalOwned Enterprises of the Russian Federation" enacted on December 21, 2001 requires the enterprises in the field of public goods, natural monopoly, national security and other strategically significant sectors to remain under state ownership or state control and provides for new procedures of the stateowned assets selling. For the first time, this law emphasizes the equal rights that all buyers of stateand municipal-owned property have, the transparency of activities in state organs and the compensation for any state-owned property being taken over by natural person or legal person. It also provides for 10 different ways of privatizing state-owned property according to the size and liquidity of the enterprises. In 2011, the shares of some large companies were taken back under state control through various means. The productivity of both privatized and state-owned enterprises was improved through restructuring enterprises and strengthening corporate governance. At the same time, it also requires preventing natural monopoly by large and state-owned enterprises and improving social responsibility of enterprises [1].

Transfer payment and redistribution. Russia is a federal country. The administrative and financial power of the federal government and local governments are governed by the Constitution of the Russian Federation, federal laws and a series of legal documents. The "Budget Code of the Russian Federation" and the "Tax Code of the Russian Federation" were amended during the M. Fradkov and V. Zubkov administrations to address different situations and tasks of those particular periods, which further adjusted the relationship 
between the federal government and local governments in budget and finance ${ }^{1}$. As a result, federal subjects gained more budgetary autonomy, and the federal government used transfer payment as a tool to ensure balanced development among regions and strengthen the influence of federal finance on local developments [2].

After the turbulent 1990s, successive administrations have attached greater importance to the livelihood of the people by increasing the residents' real income, paying more attention to the population problem, raising wages and pensions and strengthening the protection of the underprivileged groups. In order to curb the decline in Russian population, Russia has put the population issue high on its agenda. According to relevant government regulations, starting from 2007, all Russian women having (adopting) a second child can receive subsidies of up to 250000 rubles from the security department of Russian government. Families with more than one child are eligible for government help or subsidies.

Regulating the economy. In macro-control, successive administrations have mostly set a general goal of achieving fast economic growth while maintaining macro-economic stability, but the growth varied in different periods due to specific conditions inside and outside the country.

Tax neutrality. Tax revenue is the source of government funds. V. Putin has always been attaching great importance to the work of taxation during his term as president and prime minister. Under Putin's presidency, two prime ministers (M. Fradkov and M. Mishustin) used to be heads of the tax department of the government, and one prime minister (V. Zubkov) used to be director of FSFM. This shows the importance of the tax department in the Russian economy during the Putin era. However, even with the strengthening of taxation, according to statistics, the scale of Russia's "shadow economy" is still alarming in that a considerable part of taxation has not been included in Russian official statistics [3].

Guided by the goal of reducing social discontents and promoting economic development, the Russian government has taken reducing tax and expenditure as the general principle. Therefore, tax neutrality ${ }^{2}$ has become the pillar of the tax policies in the Putin era.

\footnotetext{
${ }^{1}$ Four documents were issued in 1999, 2001, 2006 and 2009 to adjust the relationship between the federal government and local governments.

2 Equity criterion and tax neutrality are the two basic principles of western public finance. Equity criterion includes horizontal equity and vertical equity. The former means that people with the same tax-paying ability should pay the same amount of tax, and the latter means that people with different tax-paying ability should pay different amounts of tax. Tax neutrality has two meanings. First, through taxation, the price paid by the society can be limited to tax so as not to bring extra loss to or burden on taxpayers or the society. Second, state taxation should refrain from affecting the normal operation of the market economy, especially the tax cannot replace the market as the decisive factor of resource allocation.
}

Successive Russian administrations have adopted measures to reduce tax rates and broaden the tax base to increase financial resources without hurting the economic development. In the government expenditure, they have reduced investment in national economy and increased investment in people's livelihood so as to enhance public satisfaction and win more public support. However, it is also due to such a philosophy that the Russian government has been falling short of the funds it needs to adjust its economic structure and make its economy less dependent on energy export, which has partially led to the economic stagnation in the Putin era.

Stabilizing exchange rate. Since July 1, 2006, Russia has lifted restrictions on capital flows and implemented a free floating exchange rate of ruble to enable its free convertibility. However, maintaining the exchange rate stable under a floating exchange rate system means that the Russian Central Bank needs to make timely moves to ensure the stability of the exchange rate using a large amount of foreign exchange reserves when necessary.

Controlling inflation. Inflation has been a very important topic in Russia. Vicious inflation occurred after the collapse of the Soviet Union, which gave rise to many problems such as social instability and decline in popular support for the government. Successve Russian administrations since then have taken reducing inflation as one of their main governance objectives.

Since 2019, Russia's inflation rate has gradually decreased, which laid a good foundation for the smooth passage of the constitutional amendment in early 2020 (Figs. 1-2).

Under the four constraining objectives of balancing budget, increasing foreign exchange, stabilizing exchange rate and reducing inflation, the Russian government has to increase energy exports to earn foreign exchange when the international crude oil price is going down. Thus, the foreign exchange reserves can be balanced since Russia's floating exchange rate regime requires the constant use of foreign exchange to keep the inflation rate under control.

Achieving rapid economic growth. Due to its consciousness and tradition of being a great power, Russia has been hoping to restore its great power status as soon as possible after the recession in the 1990s. V. Putin has repeatedly stressed the need to achieve rapid economic development at a planned annual rate of at least $5 \%$ or an ideal annual rate of $7 \sim 8 \%$ or even $10 \%$. As early as 2003 , Putin required in his state-ofthe-nation address that by 2010, GDP be doubled. The "Russian Federation's Medium-term Social and Economic Development Program 2005-2007" elaborated in 2004 continued to emphasize the high-speed economic growth and was oriented to catch up with the most developed countries, making high-speed growth the norm in the medium and long term. 


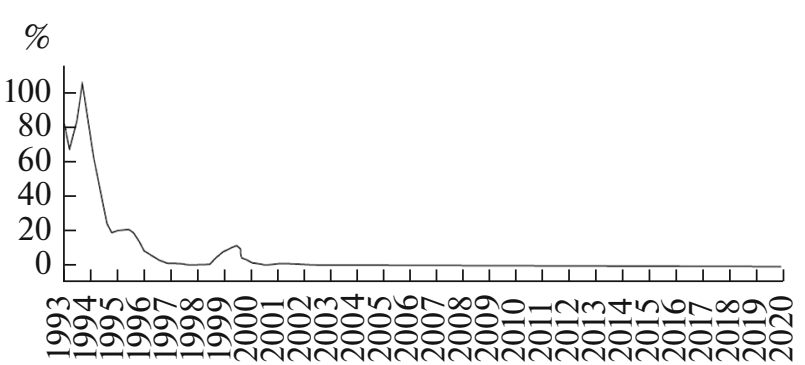

Year

Fig. 1. Dynamics of inflation rate in Russia from 1993 to 2020.

Source: https://www.inflation.eu/inflation-rates/russia/historic-inflation/cpi-inflation-russia.aspx.

In his state-of-the-nation address in March 2018, V. Putin set the target of making Russia one of the world's top five economies within six years [4]. The first presidential decree signed after V. Putin took presidency for the fourth time in May 2018 was "the Russian Federation's Strategic Tasks and National Objectives for Development by 2024" which clearly stated that "Russia will be made one of the world's top 5 economies" [5]. At the beginning of 2020, V.V. Putin expressed the hope that starting from 2021, Russia's economy will grow by $3 \%$ per year, and by 2024 , Russia will become the world's fifth largest economy.

After the Ukraine crisis in 2014, the USA and European countries began to impose economic sanctions on Russia. Under the triple blow of the economic structural recession, the fall in international energy prices and western sanction, Russia's GDP per capita dropped rapidly by half from its peak of more than US\$ 15000 in 2013. Anti-crisis plans were launched in 2015 and 2016, and an economic recovery was seen in 2017-2019. According to the Russian government's estimate, Russia would be the world's sixth largest economy in 2019 (in terms of purchasing power parity), and it was possible for it to surpass Germany to become the fifth largest economy within the next 4 years [6]. However, the Covid-19, the oil price war between Russia, Saudi Arabia and the United States in early 2020 once again brought uncertainty to Russia's economy.

Ensuring financial security. In terms of financial security, the Russian government has been striving to increase foreign exchange reserves, adjust and optimize its structure in a timely manner so as to maintain budget balance to ensure financial security.

Increasing foreign exchange reserves. Since V. Putin took office, Russia has continuously expanded its foreign exchange reserves which mainly come from energy export tariffs and some non-energy export tariffs. With the soaring international energy prices, before the 2008 international financial crisis, Russia's

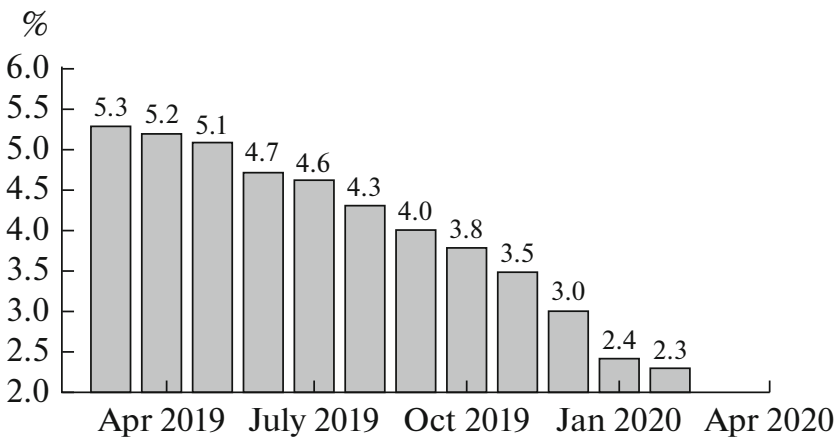

Data

Fig. 2. Inflation rate in Russia since 2019.

Source: Same as in Fig. 1.

foreign exchange reserves reached their highest level since the founding of the new federation.

In August 2006, thanks to abundant foreign exchange reserves, Russia paid off about US\$ 22 billion of the Soviet-era debts to the Paris Club ahead of schedule. In 2008, Russia's foreign exchange reserves reached US $\$ 590$ billion, a record high since the new Russia's founding. Therefore, in international credit rating, Russia successively went up by 8 grades in a short period of 6 years from 2000 to 2006 from the lowest grade (SD level, i.e. selective default) to the investment grade $(\mathrm{BBB}+)$ with Russia's investment environment being greatly improved ${ }^{3}$.

Russia's economy was severely hit by the 2008 international financial crisis and recovered slightly from 2010 to 2012. However, due to factors such as western sanctions after the Ukraine crisis, its economy declined again. After a slow growth from 2017 to 2019, Russia once again accumulated nearly US $\$ 570$ billion of foreign exchange reserves by the end of 2019. The huge foreign exchange reserves became an important guarantee for Russia in the face of unexpected events, which can be taken as an important achievement of Russia's fiscal policy in the Putin era (see Fig. 3).

When continuously increasing its foreign exchange reserves, the Russian government has also been taking active measures to optimize the structure of foreign exchange reserves. In recent years, the proportion of gold in Russia's foreign exchange reserves has gradually increased (see Fig. 4).

In recent years, especially since the end of 2017, Russia has sped up the process of "de-dollarization". The proportion of U.S. treasury bonds in Russia's foreign exchange reserves has dropped rapidly. From March 2018 to March 2019, Russia sold nearly 87\% of US treasury bonds. Especially in just two months from

\footnotetext{
${ }^{3}$ The credit rating includes nine grades: investment grade (AAA, AA, A), speculation grade (BBB, BB, B) and bankruptcy grade (CCC, CC, C). Each grade can be fine adjusted with "+"or "-" meaning" slightly higher "or" slightly lower "than the current grade, of which investment grade ranges from AAA to BBB-.
} 


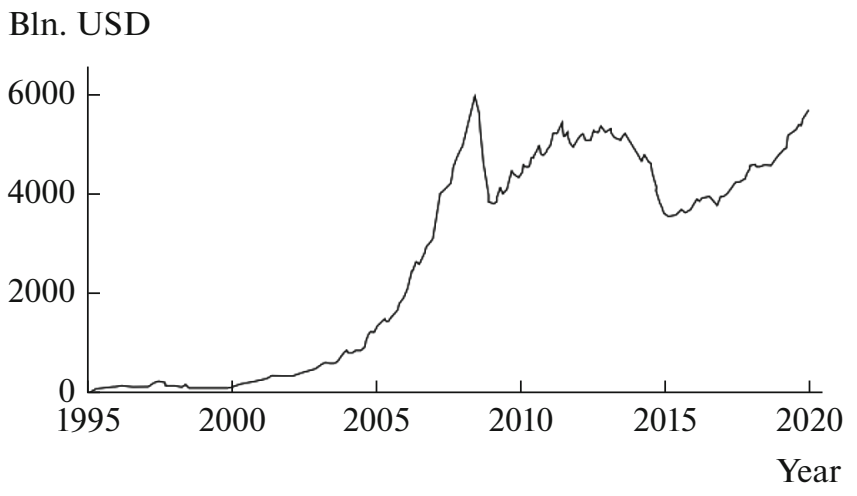

Fig. 3. Growth in Russian foreign exchange reserves in 1995-2020.

Source: Trading Economics, https://tradingeconomics.com/russia/foreign-exchange-reserves.

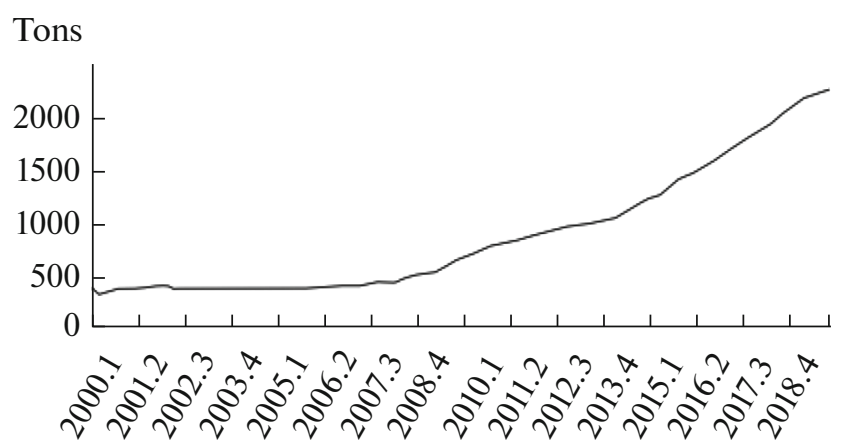

Year

Fig. 4. Quantity of gold in Russia's quarterly foreign exchange reserves from 2000 to 2018.

Source: Monthly Central Bank Statistics HTTPS://www.goldorg/goldhub/data/monthly-centralbank-statistics.

Bln. USD

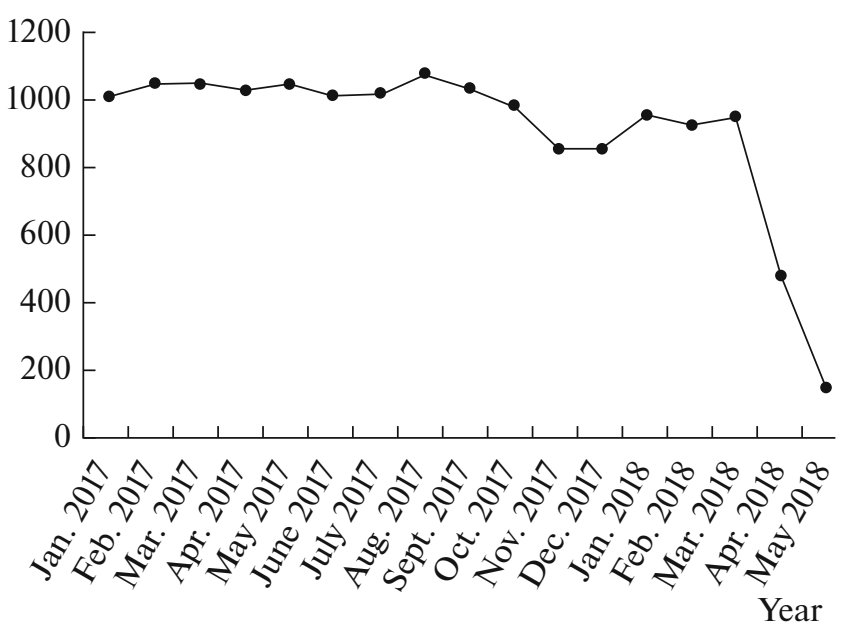

Fig. 5. US treasury debts held by Russia from Jan 2017 to May 2018.

Source: Russia Today, https://www.rt.com/business/434111-russia-dumps-treasuries-.
March to May 2018, Russia reduced its holding of US treasury bonds from 96.1 billion to 14.9 billion USD and withdrew from the list of major holders of US Treasuries [7]. US Treasuries held by Russia at the beginning of 2020 was only $6 \%$ of its peak amount (The figure slightly increased at the end of 2019 and stood at less than US $\$ 10$ billion at the beginning of 2020). Some analysts believe that Russia is likely to be counting down to "zero US debt" (see Fig. 5).

At the same time, Russia has been actively expanding its monetary cooperation with other countries. By now, Euro's share in Russia's trade settlement has increased to $42.3 \%$, which is very close to the dollar's share (46.6\%). In addition, RMB's share in Russia's foreign exchange reserves is also increasing significantly [8].

One of the most important moves was the establishment of a stabilization fund ${ }^{4}$. During A. Kudrin's term as finance minister, international crude oil prices were in an upward cycle. A stabilization fund was established by increasing crude oil export which not only helped Russia tide over the 2008 international financial crisis, but also helped it survive difficult times again and again in the following days.

Pursuing budget balance. After radical reforms in the 1990s, successive Putin-era administrations all have chosen fiscal stability over economic development as their priority. Budget balance has become the basic goal of Russian fiscal policies in the Putin era and been written into "the Budget Code of the Russian Federation". In addition, timely fiscal easing has been implemented when conditions permitted.

There was continuous fiscal surplus from 2000 to 2008. In 2008, the year of the international financial crisis, Russian Federation's fiscal deficit was the largest since its founding. The deficit subsequently decreased, and a short-term fiscal surplus appeared in 2011. But Russia's fiscal deficit worsened further from 2012 to 2017 due to a lack of inner drive for economic growth, the drop in international crude oil prices and

\footnotetext{
${ }^{4}$ On December 23, 2003, relevant laws were passed. From January 1, 2004, Russia formally established a stabilization fund based on crude oil sales. Its source of funding was the Ural oil income in excess of US $\$ 27$ per barrel. The fund was designed to be part of the Russian Federation budget and would be used when international oil prices fall and government revenues shrink. Subsequently, the Russian government finally decided to use the fund in the following ways. First, the fund would be used to buy foreign exchange (US dollars, Euros and British pounds) which then would be deposited into a special account at the central bank. Second, it would be used to purchase the long-term bonds of 14 countries including the U.S., UK and France to have its value maintained or increased. In 2008, the stabilization fund was divided into a reserve fund and a state welfare fund. It was with the support of the reserve fund that the Russian government survived the crisis and successfully completed the government budget. In 2014, the reserve fund had about 90 billion U.S. dollars. In 2018, the reserve fund no longer existed, and Russia's surplus oil income all went to the state welfare fund. By the end of 2019, the state welfare fund had about 124 billion U.S dollars.
} 


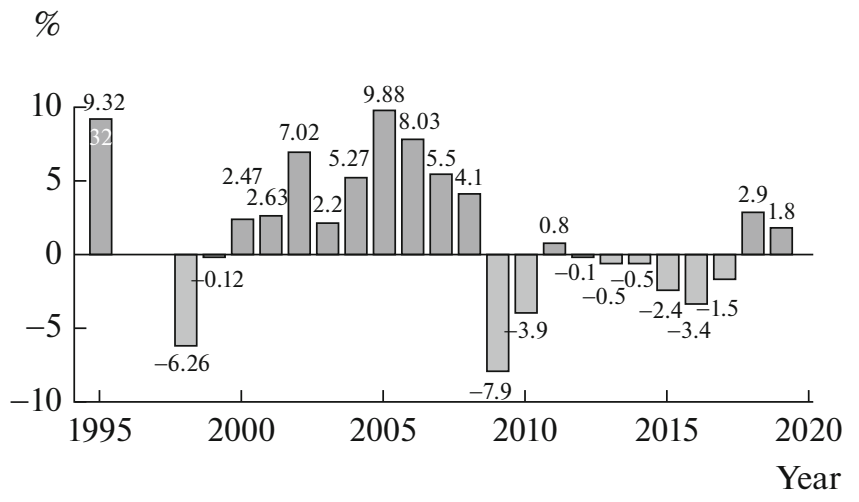

Fig. 6. Proportion of Russian government budget surplus to GDP from 1995 to 2019.

Source: Russian Government Budget Https://Trading Economics Com/Russia/Government-Budget.

western sanctions against Russia after the Ukraine crisis. 2016 saw the largest fiscal deficit in Russia in recent years, quickly followed by a restored surplus. (see Fig. 6).

The mechanism of Russia's fiscal policy. Issues such as economic development and social security were of general concern to Russian society back then. The reality in Russia required V. Putin or Russia's ruling party at that time to push forward reforms and complete the transformation at a low cost without causing social unrest. The reforms' shock to people's livelihood should be kept under control, and the economic development should be realized at the same time [9]. Under this circumstance, throughout the entire Putin era, Russia had a lot to do but very few options to choose from in terms of fiscal policy. V. Putin, as president or prime minister, has been the ultimate person in charge and the final decision-maker of Russia's fiscal policies. His political will and determination undoubtedly has played a decisive role in the choice of fiscal policies ${ }^{5}$.

According to the power structure stated in the Russian constitution, the president is responsible for major policies and development strategies, and the prime minister is responsible for their implementation. The minister of finance is the chief executive of the Russian Ministry of Finance, who is specifically responsible for fiscal revenue and expenditure, tax legislation, macro-economic policies, formulation and implementation of fiscal, financial and accounting rules and regulations, international negotiations on foreign debts and the initialing of relevant agreements. $\mathrm{He}$ is also responsible for the fiscal and tax relations between the Russian Federation and local governments and large state-owned enterprises.

\footnotetext{
${ }^{5}$ V. Putin's goals and ideas for developing Russia's economy are mainly reflected in documents such as the state-of-the-nation addresses "Russia at the Turn of the Millennium" and "Our Economic Mission" issued at the end of 1999 and in 2012.
}

During the 20-year Putin era, there have been only three finance ministers, namely, M. Kasyanov, A. Kudrin and A. Siluanov.

M. Kasyanov's financial philosophy. Kasyanov became the first deputy prime minister under the E. Primakov administration (September 11, 1996May 12, 1999) at the beginning of 1999, the minister of finance under the S. Stepashin administration (May 19, 1999-August 9, 1999), and continued his service as minister of finance after V. Putin became prime minister on August 9, 1999. When V. Putin took office as prime minister and acting president in January 2000 , M. Kasyanov served as first deputy prime minister and continued to lead the Ministry of Finance.

Kasyanov's main achievement as minister of finance was the negotiation with western countries on foreign debts and the issuance of Russian securities. His excellence in negotiation made him the "Best Minister of Finance of Eastern Europe and Central Asia in 2000", a title awarded by the famous magazine "European Currency" [10].

In the Putin era, M. Kasyanov served as finance minister for only nine months with a tight and deficitfree fiscal philosophy. He presided over the formulation of the new Russia's first deficit-free fiscal budget report. To be on a deficit-free budget means that when the government is uncertain about the future economy, it should live within its means during the economic downturn.

A. Kudrin's financial philosophy. Kudrin was an important figure who has influenced Russia's fiscal policy in the Putin era ${ }^{6}$. He was mainly responsible for the government's forecasts on internal and external social and economic developments, formulating national economic strategy, fiscal and economic policies and implementing relevant national plans and credit and tax policies, etc.

During Kudrin's term as minister of finance (May 2000-September 2011), he advocated building free market, optimizing investment environment, encouraging private investment, lifting capital flow restrictions and cracking down on domestic offshore mechanisms ${ }^{7}$. He committed himself to tax and budget reforms in macro-control, believing in low inflation, low deficit and the idea of "practicing austerity even when the coffer is full". He advocated reducing defense expenditure and no longer putting geopolitical expenditure high on the agenda. He expressed opposi-

\footnotetext{
${ }^{6}$ V. Putin appointed Kudrin as deputy prime minister and minister of finance after he took presidency for the first time in May 2000. After D. Medvedev became President in 2008, Kudrin continued to serve as deputy prime minister and minister of finance until he resigned in September 2011 due to differences with the then President Medvedev.

${ }^{7}$ Kudrin also regards the Tax Code of the Russian Federation (revised in 2004), the lifting of restrictions on capital flows (free convertibility of rubles) and the establishment of a stabilization fund as his three major achievements.
} 
tion to some infrastructure projects and national projects, and once Putin had to personally "ask him for money" for these projects. In fiscal and social policies, he cared about people's livelihood, supported the increase of pension and endorsed investment in health and education to let people have longer working years and necessary labor skills [11, 12].

It is worth mentioning that because of Kudrin's proposition and insistence that the Russian government first repay the huge foreign debt with the huge amount of petrodollars it obtained, Russia became one of the countries with the lowest foreign debt rate among the major economies in the world, which improved Russia's international status and investment environment. Kudrin also urged the establishment of a stabilization fund in Russia, which, though, being criticized by many at the beginning, became a stabilizer for Russian economy in the 2008 international financial crisis. When the international financial crisis broke out in 2008, Russia was lucky with a well-prepared stabilization fund and a relatively light burden of foreign debt (accounting for only $8 \%$ of GDP). Had Russia not set up a stabilization fund in advance and repaid its foreign debt, it would be hard for Russia to withstand the blow of the subsequent crises.

In addition, in response to the western sanctions, Kudrin advocated continued development of economic and trade relations with the West and supported currency swap and local currency settlement with China.

A. Siluanov's financial philosophy. The most important achievement of Siluanov as finance minister in the Putin era was that he led Russia through the economic crisis from 2014 to 2015 at the lowest cost. In addition, during his term of office, he begun to allow private investment in government bonds. In 2017, he started to issue government bonds (OФ3-H) to residents ${ }^{8}$. He supported the development of an electronic government bond system (Э-Бюджет) to enhance transparency. In 2018, the Ministry of Finance started submitting digital financial reports to the State Duma.

Siluanov advocated improving the investment environment, freedom of capital flow, strict control of financial risks and not boosting domestic demand through budget deficits. In macroeconomic policies, he believed that the economy needed "well-targeted" monetary and fiscal stimulus. His fiscal philosophy was more conservative, calling for careful use of reserve funds during western sanctions. In order to cope with the difficulties confronting the Russian economy as a result of the sanctions, he even proposed postponing retirement to reduce the financial burden.

Comparing the fiscal policies of the three Russian finance ministers, we can see that when M. Kasyanov took office, Russia had just survived the 1998 financial

\footnotetext{
${ }^{8}$ OФ3-H government bonds to residents.
}

crisis, and the international crude oil price begun to take off. Therefore, Kasyanov advocated tightening expenditures, living within means and striving to achieve a deficit-free finance. During A. Kudrin's term, Russia accumulated a huge amount of petrodollars very quickly when international energy prices were rising. Kudrin maintained a prudent attitude under relatively favorable conditions. When the international financial crisis came in 2008, Russia was able to tide over the difficulties safely. Russia was facing the triple crisis of declining international energy prices, economic structural problems and western sanctions. Siluanov was determined to develop economy, improve people's livelihood and increase the Russian government's support rate. During his term as minister of finance, the role of fiscal policy was very limited, but nearly 570 billion US dollars was accumulated in foreign exchange reserves with an optimized structure (reflected in the decreased proportion of US dollars and the increased proportion of gold, Euro and other international currencies), which made Russia better-prepared for the new crisis of the oil price war in early $2020^{9}$.

The philosophies adopted by the three finance ministers in different periods generally reflected the financial and economic situation of Russia in the Putin era. They all have successively adopted conservative and tight fiscal policies, which helped Russia tide over many crises. However, the excessively balanced fiscal policy was slightly conservative for President Putin whose strategy was to build a powerful and prosperous Russia. Because of this conservative and tight fiscal policy, the opposing party criticized Putin saying that Russia's economy was trapped in stagnation under his watch.

Conclusion. Reviewing the evolution of Russia's fiscal policy under Putin's watch, we can find obvious continuity and features of that particular era in Russia's fiscal philosophy, policy choices and strategic direction. As a Chinese saying implies, one can draw on others' experience and improve. The author believes that an analysis of these philosophies and measures can be an inspiration for China.

On the whole, the external environment for Russia's economic development in the Putin era has been complicated and changing. In early 2000, Russia's economy started to slowly recover, and between 2006 and 2008, it registered a double-digit growth, making Russia a "stable island of the world economy". After the blow of the 2008 international financial crisis and the western sanctions since 2014, Russia's economy managed a slow growth during the years between 2015 and 2019 and was dealt with another huge blow by the unprecedented oil price war in 2020. Reviewing the

\footnotetext{
${ }^{9}$ On March 11, 2020, due to Russia's disapproval of reduction in oil production, Saudi Arabia launched a price war on crude oil. The international crude oil price fell sharply in a short term while Russia claimed to be already well-prepared for a low international crude oil price in the future 6-10 years.
} 
whole Putin era, except for a short period of stability and development, the rest of the time was all full of turmoil and uncertainty. How to develop economy while facing increasing instability and uncertainty is a problem that all countries need to focus on in the future.

In the Putin era, in order to realize the Russian dream of building a powerful country, to achieve rapid economic development has always been the focus of Russia's development strategy. In as early as 2003, Putin proposed to double Russia's GDP within 10 years. When Russia's economy ranked no. 7 in the world, Putin set a new goal of making it the "fifth largest one in the world" ${ }^{10}$. Achieving high-speed economic development has been the general strategic goal of the Putin era, and Russia's fiscal policy, designed to create internal social stability and a peaceful external environment, is the main measure and important tool to ensure the realization of that strategic goal. As Russia is still in a special period of transition, maintaining social stability and economic development is the prerequisite for the adoption of any reform measure. Therefore, Putin's fiscal policy and measures need to be carried out in a gradual and prudent manner attending to both market and efficiency.

The Russian Ministry of Finance has control over the federal government's resources. The government uses economic levers to effectively control the macroeconomic operation, establishes a basic principle of maintaining long-term balance in the federal budget, and explores a new model for the adaptive financial relationship between the federal government and local governments. The government makes up for market failure through taking intervening measures in some fields and promotes industrial upgrading and international competitiveness through industrial policies rather than directly interfering in corporate business. It draws lessons from the past and chooses neither a rigid economic system nor a radical free market economy but a flexible and practical approach clearly separating the financial power and administrative power of the government and focusing on macro-control.

The main objective of the fiscal policy is to increase revenue and reduce expenditure. The main source of Russia's fiscal revenue in the Putin era is oil exports. If the international oil price or demand falls, Russia's fiscal revenue will drop sharply and a fiscal crisis will occur. The Russian government is very aware of this, but it is difficult to turn this around in a short period of time. In terms of reducing fiscal expenditure, successive Russian administrations have tried to reduce their administrative expenses and increase investment in production. But most of the investment finally goes to sectors that can bring quick revenue such as energy,

\footnotetext{
${ }^{10}$ Before Putin came into power in 1999, Russia's GDP ranked $13^{\text {th }}$ in the world in terms of purchasing power parity. Putin's goal of making Russia "the fifth largest economy in the world" was also in terms of purchasing power parity.
}

minerals, agriculture and consumer goods, etc., and the investment in infrastructure construction and science and technology is still insufficient. This has led to a growing "Dutch disease" with an increasingly unbalanced economic structure.

In view of the fact that Russia in the Putin era is still in the process of transformation, the government has resorted to tax reduction as a means to stimulate economic growth. Successive administrations have successively made adjustments in tax system and tax laws. Through making amendments to the Tax Code of the Russian Federation and simplifying the tax system, the government has cut tax categories, reduced tax rate, expanded tax base ${ }^{11}$, strengthened tax collection and decreased subsidies. These measures have been conducive to reducing the tax burden of enterprises, enhancing economic vitality, boosting investment activities, benefiting the accumulation of enterprise capital, expanding reproduction and improving Russia's investment environment.

In the reform of the social security system, the Russian government has tried many times to balance market efficiency and social equity, fundamentally reform the old pension insurance system, abolish the unified social tax, provide more preference for the veterans and the disabled, increase financial security provided by the government, monetize welfare services, increase capital and equipment investment and improve the medical system and management mechanism by adding more medical outlets and enhancing the quality of medical services.

Since Putin came to power, drawing upon the policies of his predecessor and considering the current situation of Russia's economy, he has adopted a more conservative fiscal policy and had it implemented throughout the whole era, strengthening macro-economic control while pursuing a balanced budget. The foreign exchange reserves (stabilization fund) have helped Russia overcome many difficulties. The floating exchange rate system has given Russia a certain degree of flexibility to cushion the international impact. The maintained low inflation rate has ensured the stability of Russian society and Putin's high support rate. It was under the combined effect of the above factors that the Russian economy stepped out of the chaos of the 1990s. However, it was also due to the conservative fiscal policy that Russia failed to build a diversified economy driven by science and technology, hence the failure in realizing the long-expected scientific and technological modernization and the lowspeed economic development in Russia as a result.

\footnotetext{
${ }^{11}$ According to the 2004 "Tax Code of the Russian Federation", tax categories were greatly reduced from 28 to 15 . In 2006 , inheritance tax and gift tax were abolished, mineral mining tax was imposed, and a special tax system was implemented for small businesses and producers of agricultural commodities. The government also promised that from 2012 onward, the average tariff level would be reduced to $7.8 \%$ in accordance with its WTO entrance commitment.
} 


\section{CONFLICT OF INTEREST}

The authors declare that they have no conflicts of interest.

\section{REFERENCES}

1. Vladimir Putin, About Our Economic Goals. https://www.pravda.ru/politics/1371575-razvitie/.

2. O. A. Kholodova, "Modern features of the development of interbudgetary transfers in the Russian Federation," Ross. Predprinimatel'stvo 18 (24) (2017).

3. Xu Wenhong, Russia and the Offshore Financial Center (Soc. Sci. Acad. Press, 2014).

4. On November 21, 2007, January 15, 2008, May 2011 and June 15, 2011, September 24, 2011, April 12, 2012, December 12, 2013, March 2018, and May 7, 2018, Putin mentioned on different occasions the idea of building Russia into the world's fifth largest economy.

5. Decree of the President of the Russian Federation of May 7, 2018. No. 204 "On National Goals and Strategic Tasks of the Development of the Russian Federation for the Period up to 2024.” http://kremlin.ru/events/president/news/57425.
6. D. A. Medvedev, "Russia will be one of the top five leading economies in the world." https://rg.ru/ 2018/09/27/medvedev-nazval-vypolnimoj-zadachuvhozhdeniia-rf-v-top-5-ekonomik-mira.html.

7. Russia Increased Its Holding of US Treasury Bonds for the First Time since February 2019. http://ru.mofcom.gov.cn/jmxw/201910/20191002907816.shtml.

8. The Share of Russian Reserves Placed in CNY Increased from 5 to almost 15 Percent? https://sputniknews.com/analysis/201901171071543542-russiaeconomy-intl-trade-reserves-dollar/.

9. V. V. Putin, Russia at the turn of millennia. http://www.ng.ru/politics/1999-12-30/4_millenium.html.

10. M. Alekseev and A. Pachkalov, Finance Ministers: From the Russian Empire to the Present Day (Al'pina Pabl., Moscow, 2019) [in Russian].

11. V. V. Putin: Kudrin was against national projects. https://www.pravda.ru/news/districts/1476582-putin_ kudrin/.

12. V. V. Putin recalled that Kudrin opposed construction of bridges and roads. https://www.rbc.ru/politics/25/02/2020/5e54c7349a7947e765c74040. 